\title{
Beneficial effects of multisensory and cognitive stimulation on age-related cognitive decline in long-term-care institutions
}

This article was published in the following Dove Press journal:

Clinical Interventions in Aging

14 February 2014

Number of times this article has been viewed

\author{
Thaís Cristina Galdino De \\ Oliveira' \\ Fernanda Cabral Soares' \\ Liliane Dias E Dias De \\ Macedo' \\ Domingos Luiz Wanderley \\ Picanço Diniz' \\ Natáli Valim Oliver Bento- \\ Torres ${ }^{1,2}$ \\ Cristovam Wanderley \\ Picanço-Diniz'
}

'Laboratory of Investigations in Neurodgeneration and Infection, Biological Sciences Institute, University Hospital João de Barros Barreto, ${ }^{2}$ College of Physical Therapy and Occupational Therapy, Federal University of Pará, Belém, Brazil
Correspondence: Cristovam Wanderley Picanço-Diniz

Laboratório de Investigações em Neurodegeneração e Infecção,

Hospital Universitário João de Barros Barreto, 4487 Rua Dos Mundurucus,

Belém, Pará 66073005, Brazil

$\mathrm{Tel} / \mathrm{fax}+55$ 9l 32016756

Email cwpdiniz@gmail.com
Abstract: The aim of the present report was to evaluate the effectiveness and impact of multisensory and cognitive stimulation on improving cognition in elderly persons living in long-term-care institutions (institutionalized [I]) or in communities with their families (noninstitutionalized [NI]). We compared neuropsychological performance using language and Mini-Mental State Examination (MMSE) test scores before and after 24 and 48 stimulation sessions. The two groups were matched by age and years of schooling. Small groups of ten or fewer volunteers underwent the stimulation program, twice a week, over 6 months ( 48 sessions in total). Sessions were based on language and memory exercises, as well as visual, olfactory, auditory, and ludic stimulation, including music, singing, and dance. Both groups were assessed at the beginning (before stimulation), in the middle (after 24 sessions), and at the end (after 48 sessions) of the stimulation program. Although the NI group showed higher performance in all tasks in all time windows compared with I subjects, both groups improved their performance after stimulation. In addition, the improvement was significantly higher in the I group than the NI group. Language tests seem to be more efficient than the MMSE to detect early changes in cognitive status. The results suggest the impoverished environment of long-term-care institutions may contribute to lower cognitive scores before stimulation and the higher improvement rate of this group after stimulation. In conclusion, language tests should be routinely adopted in the neuropsychological assessment of elderly subjects, and long-term-care institutions need to include regular sensorimotor, social, and cognitive stimulation as a public health policy for elderly persons.

Keywords: aging, multisensory stimulation, cognition, language, impoverished environment, long-term-care institutions

\section{Introduction}

Aging is associated with cognitive decline, which affects memory, language, executive functions, and the speed of information processing. This may worsen or improve depending on genetics, ${ }^{1}$ epigenetics, ${ }^{1-4}$ and lifestyle. ${ }^{5,6}$ These influences should be investigated further to guide public policies. ${ }^{7,8}$ Epidemiological studies have correlated physical and cognitive inactivity with a higher risk of age-related cognitive decline,, 10 while an active lifestyle may help prevent cognitive impairment in old age, ${ }^{11}$ a topic that was recently reviewed. ${ }^{5}$ Consistent with this view, the decline in memory and language that is associated with normal or pathological aging seems to be aggravated after institutionalization. ${ }^{12,13}$ Institutionalization is associated with an impoverished environment, as well as reduced sensorimotor and cognitive stimulation, social interactions, and physical activity, which contribute to a sedentary lifestyle. ${ }^{12}$ 
We previously examined the effects of environmental impoverishment on episodic-like and spatial memories in aged mice. ${ }^{14}$ Environmental enrichment has been defined as a combination of complex physical activity and social stimulation, reproduced in animal cages with running wheels, ropes, bridges, tunnels, and toys that are changed periodically. ${ }^{15,16}$ We demonstrated that mice maintained in enriched environments generally performed well on the spatial memory tasks on the Morris water maze and perfectly distinguished between old and recent and between displaced and stationary objects in the episodic-like memory tests, whereas individual mice maintained in impoverished cages lost those abilities. ${ }^{14}$ Morris water maze and episodic-like memory tasks have been previously detailed. ${ }^{17,18}$

In the present report, we aimed to investigate this hypothesis in elderly subjects and test the effects of multisensory and cognitive stimulation (enriched stimulation) on Mini-Mental State Examination (MMSE) and selected language-test scores. Cognitive and multisensory stimulation is an intervention for people with or without dementia, and offers a range of enjoyable activities that provide general stimulation for thinking, concentration, and memory, as well as ludic activities, such as dancing and music, usually in a social setting, such as a small group. ${ }^{15,16,19-21}$ The selected language tests included the Boston Naming Test, Semantic Verbal Fluency (SVF), Phonological Verbal Fluency (PVF), Montréal d'Evaluation de la Communication (MEC), and the Boston Cookie Theft picture-description task to measure spontaneous language production in elderly subjects, as previously described. ${ }^{22}$ We compared the scores from institutionalized elderly subjects (impoverished environment) with noninstitutionalized (enriched environment) age-matched subjects. Each subject was compared with his/herself at different time windows, before and after multisensory and cognitive stimulation. Our results indicated multisensory and cognitive stimulation should be included in permanent health policies for elderly persons living in long-term-care institutions.

\section{Materials and methods}

This study was approved by the local research ethics committee, and all principles of ethics related to research involving human subjects were observed. All subjects and/or institutions agreed to participate voluntarily and provided written consent. The present study was interventional, longitudinal, and analytical, and was developed at the Laboratory of Investigations in Neurodegeneration and Infection of the Institute of Biological Sciences at the University Hospital João de Barros Barreto in the city of Belém, Brazil.

\section{Subjects}

Participants were aged 65 or older with no history of head trauma, stroke, primary depression, or chronic alcoholism. All older participants were considered cognitively healthy with appropriate MMSE scores, adjusted for education level with the following cutoff points: illiterates, $13 ; 1-7$ years of schooling, 18; $\geq 8$ years of schooling, $26 .{ }^{23}$ All patients who met these criteria were assessed with selected language tests and the MMSE, followed by 48 sessions of multisensory and cognitive stimulation. Volunteers were divided into two groups, matched for age and years of education: institutionalized ( $I ; n=25,76.0 \pm 6.9$ years old, $4.7 \pm 4.5$ years of schooling; those who live in long-term-care institutions), and noninstitutionalized (NI; $\mathrm{n}=17,74.2 \pm 4.0$ years old, $6.8 \pm 3.6$ years of schooling; those who live in communities with their families). On average, the length of institutionalization was $8.8 \pm 3.45$ years (mean \pm standard deviation), and all long-term-care institutions were under similar internal rules and environmental conditions. NI elderly were living in the community with one or more family members.

\section{Language assessment}

Language was assessed with the following tests, detailed in Table S1.

The Boston Naming Test (shortened version) was administered and analyzed according to parameterized data for Brazil, ${ }^{24,25}$ adopting a cutoff equivalent to twelve of 15 possible figures named correctly. For SVF and PVF, tests of phonological and semantic verbal fluency were administered and computed using the following cutoff points: $<9$ points for illiterates, $<12$ points for $1-7$ years of schooling, and $<13$ points for individuals with 8 years or more of schooling. ${ }^{26}$ The Cookie Theft test was evaluated using previously published criteria on the information content of the image, including the number of key concepts, narrative efficiency, number of units of information, the total number of words, and concision ratio (ratio between the information units and the total number of words). ${ }^{27,28}$

Metaphors (explanation and alternatives), Direct Speech Acts (DSA), and Indirect Speech Acts (ISA; explanation and alternatives), Linguistic and Emotional Prosody, and Narrative Discourse (partial retelling, total retelling, and full-text comprehension) make up the MEC. The MEC battery was administered, and performance was measured in accordance with the guidelines validated for the Brazilian population. ${ }^{29}$ The cutoff points were those suggested for the age-group 60-75 years, with adjustments for education: metaphors (2-7 years of education, 19 points; $\geq 8$ years of 
schooling, 25 points), Direct and Indirect Speech (2-7 years of education, 26 points; $\geq 8$ years of schooling, 27 points), Linguistic Prosody (2-7 years of education, 6 points; $\geq 9$ years of schooling, 9 points), Emotional Prosody (2-7 years of education, 6 points; $\geq 8$ years of schooling, 8 points), partial retelling (2-7 years of education, 5 points; $\geq 8$ years of schooling, 11 points), complete retelling (2-7 years of schooling, 2 points; $\geq 8$ years of schooling, 8 points), and full-text comprehension (2-7 years of education, 5 points; $\geq 8$ years of schooling, 8 points). ${ }^{29,30}$

\section{Multisensory and cognitive interventions}

All subjects participated in the intervention program, which consisted of multisensory and cognitive activities designed for prevention of memory and language impairments. The intervention was organized as workshops for a group of ten or fewer volunteers. All sessions lasted 1 hour and were held twice a week, totaling 48 workshops. The workshops were based on a variety of recreational and ludic activities (eg, music, dance, singing, food preparation, and selecting pictures) designed to include a number of verbal, visual, auditory, tactile, olfactory, and gustatory stimuli as motivational actions for systematic exercises of language and memory. Cognitive training was based on the act of speaking, social interactions between participants, and multisensory stimulation. Each workshop had diversified activities and goals (Table S2).

All group I participants were submitted to neuropsychological tests and to the intervention program on the environment of their own long-term-care institutions, in a quiet and well-lit room with similar physical conditions, and without interruptions. The NI group subjects were also tested and submitted to the intervention program, in public places for ludic and social activities in community centers for elderly. The experimenters were the same for all participants. Because the I group were assessed in their own institution, experimenters were not blind to the group of the participant.

\section{Neuropsychological reassessment and monitoring during the intervention program}

To compare cognitive performance at the different stages of the intervention between groups, MMSE and language tests were carried out in the beginning (before stimulation), in the middle (after 24 sessions), and at the end (after 48 sessions). Thus, all patients were cognitively reassessed every 3 months.

\section{Statistical analysis}

The cognitive statuses of the elderly groups attending the intervention program were assessed by MMSE and language-test scores. A two-way analysis of variance (ANOVA) analysis was conducted: a $2 \times 2$ (group $\times$ number of sessions) as raw-change score $=\mathrm{A}-\mathrm{B}$, where $\mathrm{A}$ was "after" and $\mathrm{B}$ was baseline, or "before". A main effect of the group variable would indicate greater improvement in one group versus the other, a main effect of the time-point variable would indicate a difference in improvement from baseline to 3 months and baseline to 6 months, and an interaction between group and time point variables would indicate differences in the amount of improvement across time in both groups. BioEstat version 5.0 (http://www.mamiraua. org.br) was used for statistical analysis of the data. ${ }^{31}$ Twoway ANOVA and Bonferroni post tests were applied using Prism software (GraphPad Software, La Jolla, CA, USA) to measure possible interactions between lifestyles (I vs NI) and the number of sessions ( 24 vs 48 ) on the performance of neuropsychological tests.

\section{Results \\ MMSE and language-test results}

Statistical differences between the average MMSE scores were not significant, whereas in the language tests a number of significant differences were detected. Figure 1 gives graphical representations of mean scores and respective standard errors of neuropsychological tests indicating significant differences between time points (number of sessions) into the same group and between the same time points between groups. Note that before stimulation, the I group showed on average lower scores than the NI group in a number of tests: Boston Naming ( $\mathrm{I}=10.1 \pm 0.58$, $\mathrm{NI}=12.3 \pm 042$ [mean \pm standard error], Mann-Whitney $Z[U]=2.72 ; P=0.007), \mathrm{SVF}(\mathrm{I}=10.1 \pm 0.64, \mathrm{NI}=12.2 \pm 068$, $t=-2.15 ; P=0.04), \operatorname{PVF}(\mathrm{I}=4.92 \pm 0.72, \mathrm{NI}=6.97 \pm 085, t=-2.83$; $P=0.007)$, key concepts $(\mathrm{I}=1.76 \pm 0.35, \mathrm{NI}=3.24 \pm 023$, MannWhitney $Z[U]=2.96, P=0.003)$, metaphors - explanation $(\mathrm{I}=17.4 \pm 1.61, \mathrm{NI}=22.24 \pm 1.86, t=-2.57 ; P=0.01), \mathrm{DSA}-$ alternatives $(\mathrm{I}=6.00 \pm 0.58, \mathrm{NI}=7.88 \pm 0.74, t=-2.39 ; P=0.022)$, and Emotional Prosody ( $\mathrm{I}=4.12 \pm 0.33, \mathrm{NI}=5.18 \pm 043$, MannWhitney $Z[U]=2.63, P=0.008)$. Cognitive and multisensory stimulation reduced the language differences between the I and NI groups to PVF after 24 sessions ( $\mathrm{I}=6.94 \pm 0.71$, $\mathrm{NI}=9.29 \pm 094, t=-2.77 ; P=0.0085)$, and after 48 sessions no language differences were detected anymore. Table S3 gives all mean scores and standard errors for the I and NI groups at all time points and tests where we detected statistically 

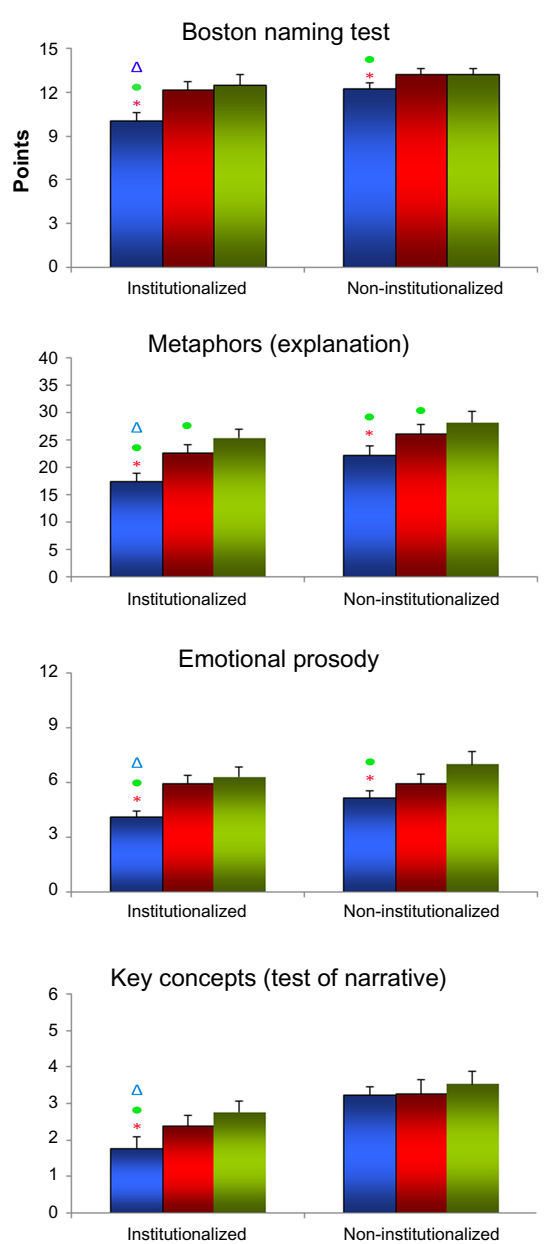

Institutionalized
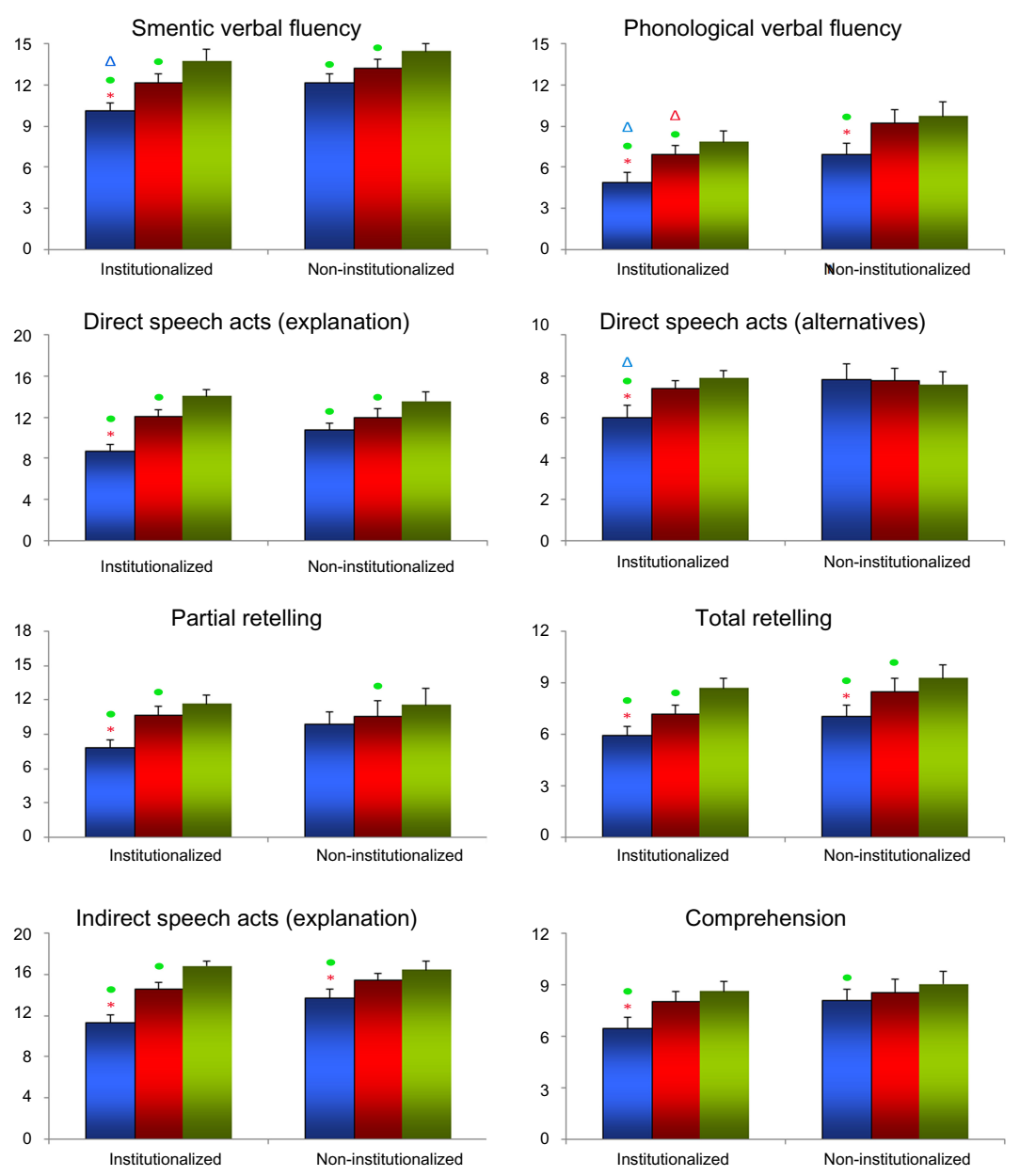

Before stimulation

After 24 sessions

ㅁfter 48 sessions

Figure I Graphical representations of mean and standard error of tests scores in the institutionalized (I) and noninstitutionalized (NI) groups across time (number of sessions: $0,24,48$ ) of elderly subjects. The mean and standard error values are indicated on the $y$-axis, and the number of sessions and groups are indicated on the $x$-axis.

Abbreviations: MMSE, mini-mental state examination; SVF, semantic verbal fluency; PVF, phonological verbal fluency; Expl, explanation; DSA, direct speech acts; ISA, indirect speech acts.

significant differences in the amount of improvement after the intervention program. Tables 1 and 2 show in detail $t$-tests or Mann-Whitney results inside each group and between groups before and after stimulation. Because the I group showed lower performance on the language tests before the stimulation, the amount of language improvement after stimulation was higher than in the NI group.

\section{Institutionalization and multisensory and cognitive stimulation}

Two groups (NI and I) $\times$ two time points (number of sessions, 24 and 48) two-way ANOVA analysis as raw-change score $=\mathrm{A}-\mathrm{B}$, where A was "after" and B was baseline, or "before," revealed group effects on performance in the following tests: Boston Naming $\left(F_{1,80}=13.13, P=0.0008\right)$, key concepts $\left(F_{1,80}=11.74, P=0.0011\right)$ from narrative, DSA - explanation $\left(F_{1,80}=4.47, P=0.03\right)$, and partial retelling
$\left(F_{1,80}=4.76, P=0.0321\right)$ from the MEC battery. The number of sessions affected the performance of SVF $\left(F_{1,80}=30.54\right.$, $P<0.0001)$ and PVF $\left(F_{1,80}=4.05, P=0.047\right)$ tests, and from the MEC battery the following tests: metaphors - explanation $\left(F_{1,80}=8.51, P=0.0046\right)$, DSA - explanation $\left(F_{1,80}=19.7\right.$, $P<0.0001)$ and alternatives $\left(F_{1,80}=4.76, P=0.032\right)$, ISA explanation $\left(F_{1,80}=22.73, P<0.0001\right)$, Emotional Prosody $\left(F_{1,80}=4.59, P=0.0352\right)$, and partial $\left(F_{1,80}=5.03, P=0.0276\right)$ and complete $\left(F_{1,80}=4.67, P=0.034\right)$ retelling and comprehension $\left(F_{1,80}=4.60, P=0.0350\right)$. The interactions between groups (NI and I) and number of sessions (0, 24, and 48) were not significant.

\section{Discussion}

This study investigated the impact of multisensory and cognitive stimulations on the scores of elderly subjects on MMSE and language tests. We also compared the test 
Table I T-tests results with $t$ - and $P$-values inside each group before and after stimulation

\begin{tabular}{|c|c|c|c|c|c|c|}
\hline \multirow[t]{2}{*}{ Tests } & \multicolumn{3}{|l|}{ Institutionalized } & \multicolumn{3}{|c|}{ Noninstitutionalized } \\
\hline & $\begin{array}{l}\text { Before } \\
\text { stimulation vs } \\
\text { after } 24 \text { sessions }\end{array}$ & $\begin{array}{l}\text { After } \\
24 \text { sessions vs } \\
\text { after } 48 \text { sessions }\end{array}$ & $\begin{array}{l}\text { Before } \\
\text { stimulation vs } \\
\text { after } 48 \text { sessions }\end{array}$ & $\begin{array}{l}\text { Before } \\
\text { stimulation vs } \\
\text { after } 24 \text { sessions }\end{array}$ & $\begin{array}{l}\text { After } \\
24 \text { sessions vs } \\
\text { after } 48 \text { sessions }\end{array}$ & $\begin{array}{l}\text { Before } \\
\text { stimulation vs } \\
\text { after } 48 \text { sessions }\end{array}$ \\
\hline \multirow[t]{2}{*}{ Boston Naming } & $t=-6.0966$ & - & $t=-5.7469$ & $t=-4.0157$ & - & $t=-3.1168$ \\
\hline & $P<0.0001$ & & $P<0.000$ I & $P=0.001$ & & $P=0.0066$ \\
\hline \multirow[t]{2}{*}{ SVF } & $t=-9.406 \mathrm{I}$ & $t=-5.7162$ & $t=-12.959$ & - & $t=-2.3952$ & $t=-2.7531$ \\
\hline & $P<0.000$ I & $P<0.000$ I & $P<0.000$ I & & $P=0.0291$ & $P=0.014 \mid$ \\
\hline \multirow[t]{2}{*}{ PVF } & $t=-8.2193$ & $t=-3.1762$ & $t=-7.522$ & $t=-4.718$ & - & $t=-3.0514$ \\
\hline & $P<0.000$ I & $P=0.004$ & $P<0.000$ I & $P<0.000$ I & & $P=0.0076$ \\
\hline Key concepts & $t=-2.179$ & - & $t=-3.3333$ & - & - & - \\
\hline (test of narrative) & $P=0.0393$ & & $P=0.0028$ & & & \\
\hline Metaphors & $t=-6.8446$ & $t=-3.3864$ & $t=-7.8527$ & $t=-3.3119$ & $t=-3.4136$ & $t=-4.3605$ \\
\hline (explanation) & $P<0.000$ I & $P=0.0024$ & $P<0.000$ I & $P=0.0044$ & $P=0.0035$ & $P<0.000$ I \\
\hline DSA & $t=-6.831$ & $t=-5.076 \mathrm{I}$ & $t=-10.453$ & - & $t=-2.2618$ & $t=-3.4267$ \\
\hline (explanation) & $P<0.000$ I & $P<0.000$ I & $P<0.000$ I & & $P=0.0379$ & $P=0.0034$ \\
\hline DSA & $t=-3.1569$ & - & $t=-3.9489$ & - & - & - \\
\hline (alternatives) & $P=0.0042$ & & $P=0.0006$ & & & \\
\hline \multirow[t]{2}{*}{ ISA (explanation) } & $t=-6.4679$ & $t=-4.9609$ & $t=-9.4186$ & $t=-3.1158$ & - & $t=-4.77$ \\
\hline & $P<0.0001$ & $P<0.0001$ & $P<0.0001$ & $P=0.0066$ & & $P<0.0001$ \\
\hline Emotional & $t=-7.0081$ & - & $t=-5.4436$ & - & $t=-2.6648$ & $t=-2.345 \mathrm{I}$ \\
\hline Prosody & $P<0.0001$ & & $P<0.0001$ & & $P=0.0169$ & $P=0.0322$ \\
\hline \multirow[t]{2}{*}{ Partial retelling } & $t=-6.5338$ & $t=-2.522$ & $t=-6.0136$ & - & $t=-2.4874$ & - \\
\hline & $P<0.0001$ & $P=0.0187$ & $P<0.0001$ & & $P=0.0242$ & \\
\hline \multirow[t]{2}{*}{ Total retelling } & $t=-2.8284$ & $t=-6.1954$ & $t=-4.9847$ & $t=-3.732$ & $t=-2.4245$ & $t=-4.4362$ \\
\hline & $P=0.0093$ & $P<0.0001$ & $P<0.0001$ & $P=0.0018$ & $P=0.0275$ & $P<0.0001$ \\
\hline \multirow[t]{2}{*}{ Comprehension } & $t=-3.9192$ & - & $t=-5.2553$ & - & - & $t=-2.3154$ \\
\hline & $P=0.0006$ & & $P<0.0001$ & & & $P=0.034 I$ \\
\hline
\end{tabular}

Abbreviations: MMSE, mini-mental state examination; SVF, semantic verbal fluency; PVF, phonological verbal fluency; Expl, explanation; DSA, direct speech acts; ISA, indirect speech acts.

performance of the NI and I groups. The MMSE was used to select cognitively normal volunteers who subsequently underwent evaluations before and after multisensory and cognitive interventions. The two groups were matched for age and education. Both groups attended a series of 48 workshops involving multisensory and cognitive stimulation, and were evaluated before, during, and after the stimulation sessions ended. The results demonstrated that language tests were more sensitive than the classic screening test (MMSE) for detecting age-related cognitive decline and evaluating the cognitive progress. Previously, ${ }^{12}$ it was determined that I and NI groups differ in physical activity and performance on neuropsychological tests. In the present study, the I group showed worse cognitive performance when compared to the NI group, which may be due to a higher degree of sedentary lifestyle and poor cognitive stimulation. After the intervention program, we saw significant improvement in both groups, with the stimulation sessions having the greatest impact on the I group, whose improvement on cognitive tests showed no ceiling effect, as was observed for the NI group.

\section{Age-related cognitive decline} and an impoverished environment

Experimental data from rodents indicated there was cognitive decline in learning and memory that was associated with aging; in addition, these changes were related to structural and functional changes in hippocampal formation, which such functions depend on. ${ }^{32-34}$ Several experimental studies compared cognitive performance among animals living in an enriched environment and an impoverished environment for sensory input and motor activities. These studies found animals of the same genetic variety show hippocampal cognitive dysfunction after living in impoverished environments, with deficits in learning and spatial memory. ${ }^{35,36} \mathrm{An}$ experimental study in mice conducted in our laboratory ${ }^{14}$ determined that mnemonic skills deteriorated more intensely with impaired spatial and episodic-like memories when the aging process occurred in an impoverished environment. Accordingly, older animals that were housed in the enriched environment showed preserved learning and memory in all tests, suggesting the mechanisms of consolidation and recovery for these types of memory were maintained by somatomotor and cognitive 
Table 2 Institutionalized versus noninstitutionalized $t$ - or MannWhitney test results, indicating significant differences between baseline, 24, and 48 sessions

\begin{tabular}{|c|c|c|c|}
\hline \multirow[t]{2}{*}{ Tests } & \multicolumn{3}{|c|}{ Institutionalized vs noninstitutionalized } \\
\hline & $\begin{array}{l}\text { Before } \\
\text { stimulation }\end{array}$ & $\begin{array}{l}\text { After } \\
24 \text { sessions }\end{array}$ & $\begin{array}{l}\text { After } \\
48 \text { sessions }\end{array}$ \\
\hline Boston Naming & $\begin{array}{l}\text { Mann-Whitney } \\
Z(U)=2.7162 \\
P=0.0066\end{array}$ & - & - \\
\hline SVF & $\begin{array}{l}t=-2.1506 \\
P=0.0375\end{array}$ & - & - \\
\hline PVF & $\begin{array}{l}t=-2.8283 \\
P=0.0073\end{array}$ & $\begin{array}{l}t=-2.7709 \\
P=0.0085\end{array}$ & - \\
\hline $\begin{array}{l}\text { Key concepts } \\
\text { (test of narrative) }\end{array}$ & $\begin{array}{l}\text { Mann-Whitney } \\
Z(U)=2.9597 \\
P=0.0031\end{array}$ & - & - \\
\hline $\begin{array}{l}\text { Metaphors } \\
\text { (explanation) }\end{array}$ & $\begin{array}{l}t=-2.5675 \\
P=0.014 I\end{array}$ & - & - \\
\hline DSA (explanation) & - & - & - \\
\hline DSA (alternatives) & $\begin{array}{l}t=-2.3952 \\
P=0.022\end{array}$ & - & - \\
\hline ISA (explanation) & - & - & - \\
\hline Emotional & Mann-Whitney & - & - \\
\hline Prosody & $\begin{array}{l}Z(U)=2.6308 \\
P=0.0085\end{array}$ & & \\
\hline Partial retelling & - & - & - \\
\hline Total retelling & - & - & - \\
\hline Comprehension & - & - & - \\
\hline
\end{tabular}

Abbreviations: MMSE, mini-mental state examination; SVF, semantic verbal fluency; PVF, phonological verbal fluency; Expl, explanation; DSA, direct speech acts; ISA, indirect speech acts.

stimulations in the enriched condition. Another recent study tested how environmental enrichment can reverse the changes in spatial learning and memory that are impaired by advancing age in rats, concomitantly with neurogenesis. Although the performance of young rats overcame that of aged rats, aged rats exposed to enriched environments performed better in all behavioral measures than aged rats housed individually. ${ }^{37}$

The human cognitive decline associated with aging seems to be a consequence of neural network impairments, ${ }^{38-41}$ which is mainly associated with vascular, ${ }^{42,43}$ inflammatory, ${ }^{44-46}$ metabolic, ${ }^{47-49}$ and oxidative ${ }^{50,51}$ changes. These pathophysiological neural network changes are worsened by a sedentary lifestyle, ${ }^{52-54}$ and physical and cognitive stimulation on a regular basis seem to delay these damages in both healthy and demented older persons. ${ }^{55} \mathrm{In}$ a recent review, Volkers and Scherder ${ }^{12}$ showed that sedentary and lonely elderly subjects living in long-term care institutions (impoverished conditions) had worse cognitive performance and cognitively decline more quickly than individuals who had active lives in the community with their families (enriched conditions). These authors demonstrated that institutionalization exacerbates the cognitive decline, probably due to the lower degree of cognitive and physical activities in these environments. Institutionalization is associated with excessive time in bed, and when out of bed, elderly persons remain inactive and passive. When using scales to assess the quality of life of the institutionalized elderly, there was greater impairment in the usual activities needed for daily living, and aggravating factors were anxiety, depression, and lack of family support. ${ }^{56}$ In this context, the reduced levels of physical and cognitive activities in the institutionalized environment favor cognitive decline, depression, and decreasing quality of life. The worse cognitive performance among the elderly in this study seems to be related to the impoverished environment of long-term-care institutions, which were improved by the implementation of workshops and multisensory stimulation. Therefore, we suggest the plasticity of the institutionalized elderly brain is preserved, and could be enhanced by regular cognitive and multisensory interventions.

\section{Age-related cognitive decline and language neuropsychological tests}

The decrease in language skills, in association with semantic memory, seems to be one of the first consequences of aging on cognitive performance, but is also seen in early stage Alzheimer's disease ${ }^{57}$ The impairment of semantic memory suggests there are neural compensation mechanisms, such as retrieving words integrated with visual information. ${ }^{58}$ In a recent study, ${ }^{59}$ Cotelli et al demonstrated that performance on tests of naming was associated with activation of the left frontal and temporal areas in both young and elderly subjects, but that this activity included the prefrontal cortex during normal aging, indicating the presence of pathological reorganization of these pathways during aging. Sugarman et $\mathrm{al}^{57}$ determined the naming test associated with functional magnetic resonance imaging has predictive value for the risk of Alzheimer's disease and should be used as a presymptomatic biomarker, justifying our choice of using cognitive skill tests involving language functions. Other findings suggest similar sensitivities with tests of SVF, demonstrating that possible changes are relevant for the diagnosis of early cognitive decline and to measure its worsening. ${ }^{60}$ It has been proposed that the decrease in verbal working memory and reduced reading comprehension are early indicators of aging cognitive decline, ${ }^{61}$ and that patients in the early stages of Alzheimer's disease exhibit language deficits that are expressed as a reduction in syntactic complexity, ${ }^{62}$ using the analysis of language elicited from the Cookie Theft 
concept. This test requires the participant to describe what is happening in the picture. The verbal description of the figure was recorded and then transcribed from the MP3 file, following standard procedures. ${ }^{63}$ In this study, we employed the Cookie Theft narrative test and evaluated a series of linguistic functions. We found that three of four indicators improved after multisensory and cognitive stimulation, namely key concepts, narrative efficiency, and information units, and this effect was significantly greater in the I group. These findings confirmed the importance of our choice to assess language disorders associated with age-related cognitive decline that are aggravated by the deleterious effects of the impoverished environment of long-term-care institutions.

\section{Beneficial implications of a multisensory and cognitive stimulation intervention program for the institutionalized elderly}

The set of data obtained here in healthy aging subjects, and findings from other studies in both healthy and demented elderly subjects, demonstrate it is possible to improve cognitive ${ }^{55,64-66}$ and perceptual ${ }^{67-70}$ functions through training and exercises that make up sensory/motor and cognitive-oriented stimulation programs for the elderly. As recommended elsewhere, ${ }^{71,72}$ our intervention program was designed to take advantage of presumed compensatory mechanisms associated with multisensory/motor and cognitive stimulation, thereby limiting functional decline in higher cognitive performance in aging people. However, a previous report ${ }^{73}$ found that cognitive stimulation programs differ in duration, strategies, and the methods employed; therefore, there are widely diverse effects and maintenance of long-term results.

Another important finding was that the NI persons submitted to our interventional program showed less increase in neuropsychological tests performance than the I group. We suggest that the enriched environment interactions and socialization in the community lifestyles of the NI group exposed these subjects to a greater amount of cognitive and multisensory stimulation, decreasing the magnitude of the effects of therapeutic sessions. In line with these findings, other studies suggest that elderly subjects without any concomitant cognitive stimulation may benefit relatively more from training than older people with parallel cognitive stimulation. ${ }^{74}$ However, it is necessary to consider that since there was no comparison with a "no intervention" control group, it is impossible to distinguish any improvements from a practice effect, but because a possible practice effect would be present in both groups, it is reasonable to suppose that this practice effect would not explain significant differences between the I and NI groups.

\section{Author contributions}

TCGO, FCS, NVOBT, and CWPD designed the study and participated in the experimental design. TCGO, FCS, and LDDM performed the experiments. TCGO, NVOBT, and CWPD participated in the data analysis and organized the manuscript draft. All authors read and approved the final manuscript.

\section{Acknowledgments}

This work was supported by Programa Pesquisa para o SUS: Gestão Compartilhada em Saúde (PPSUS) - Ministério da Saúde/Conselho Nacional de Desenvolvimento Científico e Tecnológico (CNPq)/Fundação de Amparo à Pesquisa do Estado do Pará (FAPESPA)/Secretaria de Saúde do Estado do Pará (SESPA) (grants 051/2007 and 013/2009); Agência Brasileira da Inovação (FINEP)/Fundação de Amparo e Desenvolvimento da Pesquisa (FADESP) (grant 01.04.0043.00); and Pró-Reitoria de Pesquisa (PROPESPUFPA)/Fundação de Amparo e Desenvolvimento da Pesquisa (FADESP).

\section{Disclosure}

The authors report no conflicts of interest in this work.

\section{References}

1. Brooks-Wilson AR. Genetics of healthy aging and longevity. Hum Genet. 2013;132(12):1323-1338.

2. Martin SL, Hardy TM, Tollefsbol TO. Medicinal chemistry of the epigenetic diet and caloric restriction. Curr Med Chem. 2013;20(32): 4050-4059.

3. Ayissi VB, Ebrahimi A, Schluesenner H. Epigenetic effects of natural polyphenols: a focus on SIRT1-mediated mechanisms. Mol Nutr Food Res. Epub July 23, 2013.

4. Johansson A, Enroth S, Gyllensten U. Continuous aging of the human DNA methylome throughout the human lifespan. PLoS One. 2013;8(6): 67378

5. Lovden M, Xu W, Wang HX. Lifestyle change and the prevention of cognitive decline and dementia: what is the evidence? Curr Opin Psychiatry. 2013;26(3):239-243.

6. El Assar M, Angulo J, Rodríguez-Mañas L. Oxidative stress and vascular inflammation in aging. Free Radic Biol Med. 2013;65C:380-401.

7. Alexander GE, Ryan L, Bowers D, et al. Characterizing cognitive aging in humans with links to animal models. Front Aging Neurosci. 2012;4:21.

8. Burke SN, Ryan L, Barnes CA. Characterizing cognitive aging of recognition memory and related processes in animal models and in humans. Front Aging Neurosci. 2012;4:15.

9. Tyndall AV, Davenport MH, Wilson BJ, et al. The brain-in-motion study: effect of a 6-month aerobic exercise intervention on cerebrovascular regulation and cognitive function in older adults. BMC Geriatr. 2013;13:21.

10. Erickson KI, Weinstein AM, Lopez OL. Physical activity, brain plasticity, and Alzheimer's disease. Arch Med Res. 2012;43(8):615-621. 
11. Small BJ, Dixon RA, McArdle JJ, Grimm KJ. Do changes in lifestyle engagement moderate cognitive decline in normal aging? Evidence from the Victoria Longitudinal Study. Neuropsychology. 2012;26(2): $144-155$.

12. Volkers KM, Scherder EJ. Impoverished environment, cognition, aging and dementia. Rev Neurosci. 2011;22(3):259-266.

13. Zalik E, Zalar B. Differences in mood between elderly persons living in different residential environments in Slovenia. Psychiatr Danub. 2013;25(1):40-48.

14. Diniz D, Foro CA, Rego CM, et al. Environmental impoverishment and aging alter object recognition, spatial learning, and dentate gyrus astrocytes. Eur J Neurosci. 2010;32(3):509-519.

15. Woods B, Aguirre E, Spector AE, Orrell M. Cognitive stimulation to improve cognitive functioning in people with dementia. Cochrane Database Syst Rev. 2012;2:CD005562.

16. Salotti P, De Sanctis B, Clementi A, Fernandez Ferreira M, De Silvestris T. Evaluation of the efficacy of a cognitive rehabilitation treatment on a group of Alzheimer's patients with moderate cognitive impairment: a pilot study. Aging Clin Exp Res. 2013;25(4): 403-409.

17. Sharma S, Rakoczy S, Brown-Borg H. Assessment of spatial memory in mice. Life Sci. 2010;87(17-18):521-536.

18. Dere E, Huston JP, De Souza Silva MA. Episodic-like memory in mice: simultaneous assessment of object, place and temporal order memory. Brain Res Brain Res Protoc. 2005;16(1-3):10-19.

19. Kwok T, Wong A, Chan G, et al. Effectiveness of cognitive training for Chinese elderly in Hong Kong. Clin Interv Aging. 2013;8: 213-219.

20. Kattenstroth JC, Kalisch T, Holt S, Tegenthoff M, Dinse HR. Six months of dance intervention enhances postural, sensorimotor, and cognitive performance in elderly without affecting cardio-respiratory functions. Front Aging Neurosci. 2013;5:5.

21. Alain C, Zendel BR, Hutka S, Bidelman GM. Turning down the noise: the benefit of musical training on the aging auditory brain. Hear Res. Epub July 2, 2013.

22. Ardila A, Rosselli M. Spontaneous language production and aging: sex and educational effects. Int J Neurosci. 1996;87(1-2):71-78.

23. Bertolucci PH, Brucki SM, Campacci SR, Juliano Y. [The Mini-Mental State Examination in a general population: impact of educational status]. Arq Neuropsiquiatr. 1994;52(1):1-7. Portuguese.

24. Bertolucci PH, Okamoto IH, Toniolo JN, Ramos LR, Bruki SM. Desempenho da população brasileira na bateria neuropsicológica do Consortium to Establish a Registry for Alzheimer's Disease (CERAD). Rev Psiquiatr Clin. 1998;25:80-83.

25. Bertolucci PH, Okamoto IH, Brucki SM, Siviero MO, Toniolo Neto J, Ramos LR. Applicability of the CERAD neuropsychological battery to Brazilian elderly. Arq Neuropsiquiatr. 2001;59(3-A):532-536.

26. Caramelli P, Carthery-Goulart MT, Porto CS, Charchat-Fichman H, Nitrini R. Category fluency as a screening test for Alzheimer disease in illiterate and literate patients. Alzheimer Dis Assoc Disord. 2007;21(1): 65-67.

27. Forbes-McKay KE, Venneri A. Detecting subtle spontaneous language decline in early Alzheimer's disease with a picture description task. Neurol Sci. 2005;26(4):243-254.

28. Groves-Wright K, Neils-Strunjas J, Burnett R, O’Neill MJ. A comparison of verbal and written language in Alzheimer's disease. $J$ Commun Disord. 2004;37(2):109-130.

29. Fonseca RP, Joanette Y, Côté H, et al. Brazilian version of the Protocole Montreal d'Evaluation de la Communication (Protocole MEC): normative and reliability data. Span J Psychol. 2008;11(2):678-688.

30. Fonseca RP, Parente MA, Côté H, Ska B, Joanette Y. Introducing a communication assessment tool to Brazilian speech therapists: the MAC Battery. Pro Fono. 2008;20(4):285-291.

31. Ayres M, M AJ, Ayres D, Santos AS. BioEstat 5.0: Aplicações Estatísticas nas Areas das Ciências Biológicas e Médicas [BioEstat 5.0: Statistical applications in the Biological and Medical Sciences]. Belém, Brazil: Sociedade Civil Mamirauá; 2007.
32. Teather LA, Magnusson JE, Chow CM, Wurtman RJ. Environmental conditions influence hippocampus-dependent behaviours and brain levels of amyloid precursor protein in rats. Eur J Neurosci. 2002;16(12): 2405-2415.

33. Frick KM, Fernandez SM. Enrichment enhances spatial memory and increases synaptophysin levels in aged female mice. Neurobiol Aging. 2003;24(4):615-626.

34. Rosenzweig ES, Barnes CA. Impact of aging on hippocampal function: plasticity, network dynamics, and cognition. Prog Neurobiol. 2003; 69(3): 143-179.

35. Teather LA, Wurtman RJ. Dietary CDP-choline supplementation prevents memory impairment caused by impoverished environmental conditions in rats. Learn Mem. 2005;12(1):39-43.

36. Iso H, Simoda S, Matsuyama T. Environmental change during postnatal development alters behaviour, cognitions and neurogenesis of mice. Behav Brain Res. 2007;179(1):90-98.

37. Speisman RB, Kumar A, Rani A, et al. Environmental enrichment restores neurogenesis and rapid acquisition in aged rats. Neurobiol Aging. 2013;34(1):263-274.

38. Onoda K, Ishihara M, Yamaguchi S. Decreased functional connectivity by aging is associated with cognitive decline. J Cogn Neurosci. 2012;24(11):2186-2198.

39. Kalkstein J, Checksfield K, Bollinger J, Gazzaley A. Diminished top-down control underlies a visual imagery deficit in normal aging. J Neurosci. 2011;31(44):15768-15774.

40. Gluck MA, Myers CE, Nicolle MM, Johnson S. Computational models of the hippocampal region: implications for prediction of risk for Alzheimer's disease in non-demented elderly. Curr Alzheimer Res. 2006;3(3):247-257.

41. Salami A, Eriksson J, Nyberg L. Opposing effects of aging on largescale brain systems for memory encoding and cognitive control. J Neurosci. 2012;32(31):10749-10757.

42. Jellinger KA. Pathology and pathogenesis of vascular cognitive impairment - a critical update. Front Aging Neurosci. 2013;5:17.

43. Henry-Feugeas MC, Koskas P. Cerebral vascular aging: extending the concept of pulse wave encephalopathy through capillaries to the cerebral veins. Curr Aging Sci. 2012;5(2):157-167.

44. Sama DM, Norris CM. Calcium dysregulation and neuroinflammation: discrete and integrated mechanisms for age-related synaptic dysfunction. Ageing Res Rev. 2013;12(4):982-995.

45. Keleshian VL, Modi HR, Rapoport SI, Rao JS. Aging is associated with altered inflammatory, arachidonic acid cascade, and synaptic markers, influenced by epigenetic modifications, in the human frontal cortex. J Neurochem. 2013;125(1):63-73.

46. Varnum MM, Ikezu T. The classification of microglial activation phenotypes on neurodegeneration and regeneration in Alzheimer's disease brain. Arch Immunol Ther Exp (Warsz). 2012;60(4): 251-266.

47. Craft S, Foster TC, Landfield PW, Maier SF, Resnick SM, Yaffe K. Session III: Mechanisms of age-related cognitive change and targets for intervention: inflammatory, oxidative, and metabolic processes. J Gerontol A Biol Sci Med Sci. 2012;67(7):754-759.

48. Birdsill AC, Carlsson CM, Willette AA, et al. Low cerebral blood flow is associated with lower memory function in metabolic syndrome. Obesity (Silver Spring). 2013;21(7):1313-1320.

49. Anton S, Leeuwenburgh C. Fasting or caloric restriction for healthy aging. Exp Gerontol. 2013;48(10):1003-1005.

50. Flynn JM, Melov S. SOD2 in mitochondrial dysfunction and neurodegeneration. Free Radic Biol Med. 2013;62:4-12.

51. Johnson EJ, Vishwanathan R, Johnson MA, et al. Relationship between serum and brain carotenoids, alpha-tocopherol, and retinol concentrations and cognitive performance in the oldest old from the Georgia Centenarian Study. J Aging Res. 2013;2013:951786.

52. Ballesteros S, Mayas J, Reales JM. Does a physically active lifestyle attenuate decline in all cognitive functions in old age? Curr Aging Sci. 2013;6(2):189-198. 
53. Nemati Karimooy H, Hosseini M, Nemati M, Esmaily HO. Lifelong physical activity affects mini mental state exam scores in individuals over 55 years of age. J Bodyw Mov Ther. 2012;16(2):230-235.

54. Takata Y, Ansai T, Soh I, et al. Physical fitness and cognitive function in an 85-year-old community-dwelling population. Gerontology. 2008;54(6):354-360.

55. Cheng ST, Chow PK, Song YQ, et al. Mental and physical activities delay cognitive decline in older persons with dementia. Am J Geriatr Psychiatry. Epub February 6, 2013.

56. Estrada A, Cardona D, Segura AM, Chavarriaga LM, Ordonez J, Osorio JJ. [Quality of life in institutionalized elderly people of Medellín]. Biomedica. 2011;31(4):492-502. [Spanish.]

57. Sugarman MA, Woodard JL, Nielson KA, et al. Functional magnetic resonance imaging of semantic memory as a presymptomatic biomarker of Alzheimer's disease risk. Biochim Biophys Acta. 2012;1822(3): 442-456.

58. Wierenga CE, Stricker NH, McCauley A, et al. Altered brain response for semantic knowledge in Alzheimer's disease. Neuropsychologia. 2011;49(3):392-404.

59. Cotelli M, Manenti R, Brambilla M, Zanetti O, Miniussi C. Naming ability changes in physiological and pathological aging. Front Neurosci. 2012;6:120.

60. Hall JR, Harvey M, Vo HT, O’Bryant SE. Performance on a measure of category fluency in cognitively impaired elderly. Neuropsychol Dev Cogn B Aging Neuropsychol Cogn. 2011;18(3):353-361.

61. DeDe G, Caplan D, Kemtes K, Waters G. The relationship between age, verbal working memory, and language comprehension. Psychol Aging. 2004;19(4):601-616.

62. Ahmed S, de Jager CA, Haigh AM, Garrard P. Logopenic aphasia in Alzheimer's disease: clinical variant or clinical feature? J Neurol Neurosurg Psychiatry. 2012;83(11):1056-1062.

63. Garrard P, Haigh AM, de Jager CA. Techniques for transcribers: assessing and improving consistency in transcripts of spoken language. Lit Linguist Comput. 2011;26(4):371-388.
64. Fitzsimmons S, Buettner LL. Therapeutic recreation interventions for need-driven dementia-compromised behaviors in communitydwelling elders. Am J Alzheimers Dis Other Demen. 2002;17(6): 367-381.

65. Park DC, Bischof GN. The aging mind: neuroplasticity in response to cognitive training. Dialogues Clin Neurosci. 2013;15(1):109-119.

66. Ruthirakuhan M, Luedke AC, Tam A, Goel A, Kurji A, Garcia A. Use of physical and intellectual activities and socialization in the management of cognitive decline of aging and in dementia: a review. J Aging Res. 2012;2012:384875.

67. Legault I, Faubert J. Perceptual-cognitive training improves biological motion perception: evidence for transferability of training in healthy aging. Neuroreport. 2012;23(8):469-473.

68. Legault I, Allard R, Faubert J. Healthy older observers show equivalent perceptual-cognitive training benefits to young adults for multiple object tracking. Front Psychol. 2013;4:323.

69. Bower JD, Andersen GJ. Aging, perceptual learning, and changes in efficiency of motion processing. Vision Res. 2012;61:144-156.

70. Bower JD, Watanabe T, Andersen GJ. Perceptual learning and aging: improved performance for low-contrast motion discrimination. Front Psychol. 2013;4:66.

71. Kraft E. Cognitive function, physical activity, and aging: possible biological links and implications for multimodal interventions. Neuropsychol Dev Cogn B Aging Neuropsychol Cogn. 2012;19(1-2) 248-263.

72. Thom JM, Clare L. Rationale for combined exercise and cognitionfocused interventions to improve functional independence in people with dementia. Gerontology. 2011;57(3):265-275.

73. Kolanowski A, Buettner L. Prescribing activities that engage passive residents. An innovative method. J Gerontol Nurs. 2008;34(1): $13-18$.

74. Kwok TC, Chau WW, Yuen KS, et al. Who would benefit from memory training? A pilot study examining the ceiling effect of concurrent cognitive stimulation. Clin Interv Aging. 2011;6:83-88. 


\section{Supplementary materials}

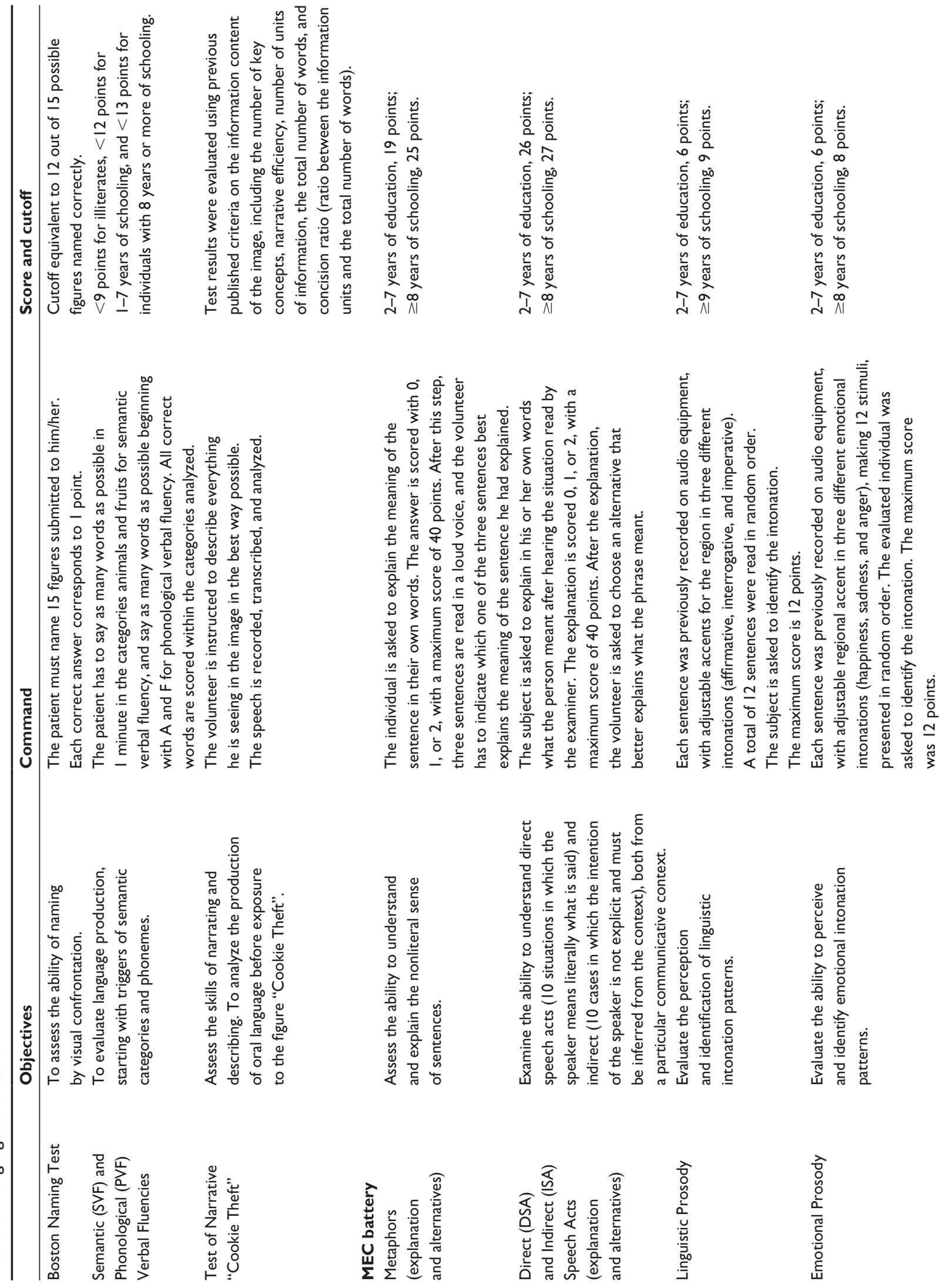



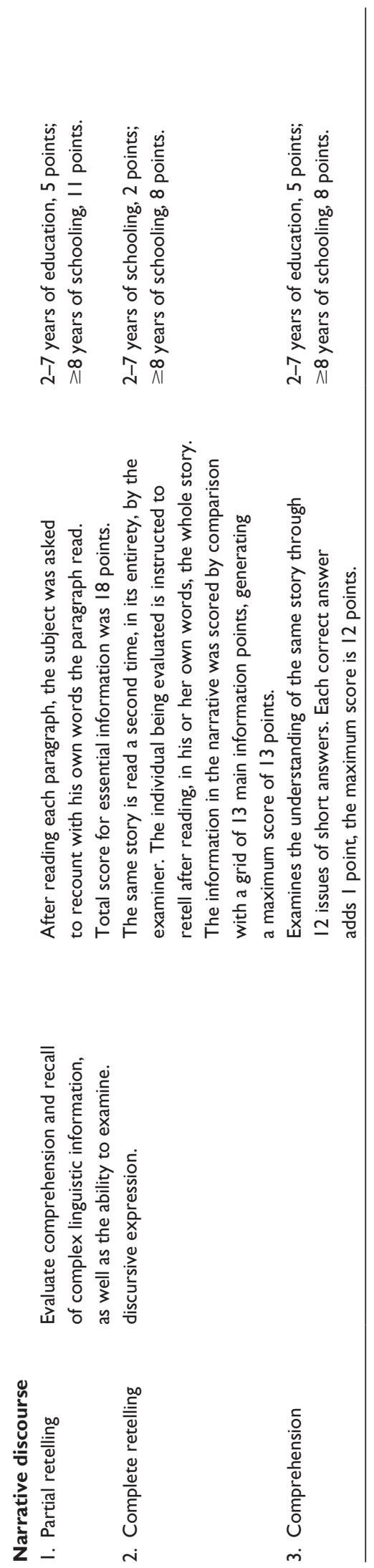
Table S2 Detailed organization of the workshops for multisensory and cognitive stimulation

\begin{tabular}{|c|c|c|}
\hline Workshops & Stimuli & Activities \\
\hline \multicolumn{3}{|c|}{ First series of workshops } \\
\hline Ist & Autobiographical memory & Recalling events of their personal lives. \\
\hline 2nd, 3rd & Attention & Stimuli through the techniques of attention in a group. \\
\hline 4th, 5th & $\begin{array}{l}\text { Phonological } \\
\text { and semantic }\end{array}$ & $\begin{array}{l}\text { Activation of phonological and semantic networks of language through double-bingo lotto for } \\
\text { semantic category and phoneme. }\end{array}$ \\
\hline 6th, 7th & $\begin{array}{l}\text { Phonological } \\
\text { and semantic }\end{array}$ & $\begin{array}{l}\text { Bingo lotto of letters where networking phonological and syntactic language are activated through } \\
\text { the bingo cartouches. }\end{array}$ \\
\hline 8th, 9th & Syntax & $\begin{array}{l}\text { List of words containing nouns and verbs: the group had to identify and transform the names into } \\
\text { verbs and verbs into names, explaining their meaning, providing a synonym and elaborating phrases. }\end{array}$ \\
\hline I0th, IIth & Prospective memory & Thematic workshops: politics, health, education, public safety, etc. Personal positioning. \\
\hline 12 th-15th & $\begin{array}{l}\text { Sound, music } \\
\text { and discourse }\end{array}$ & $\begin{array}{l}\text { Use of sound and music: music competition, identification of sounds and their representations, their } \\
\text { music, and lyrics. }\end{array}$ \\
\hline 16th-19th & Sound and motor & $\begin{array}{l}\text { Use of sound stimuli and motor activities associated with body movements. Dance videos, identifying } \\
\text { the movements and rhythm. Free dance. }\end{array}$ \\
\hline 20th, 2 Ist & Tactile and discursive & Tactile stimuli blindfolded identification of objects and their function, surface sensitivity. \\
\hline 22nd-24th & $\begin{array}{l}\text { Olfactory, gustatory, } \\
\text { and discursive }\end{array}$ & $\begin{array}{l}\text { Olfactory and gustatory stimuli, identification of odors and flavors and their representations, } \\
\text { exchange recipes and tasting. }\end{array}$ \\
\hline \multicolumn{3}{|c|}{ Second series of workshops } \\
\hline 25 th-30th & Visual and discursive & Use of images, pictures, and photos as triggers for speech, pairing visual and verbal information. \\
\hline 3 Ist, 32nd & Semantic memory & Working with the categorization and association intruders. \\
\hline 33rd, 34th & Language comprehension & Activities with proverbs and popular sayings. Task working words and phrases with double meanings. \\
\hline 35th, 36th & Memory and discourse & Folk legends and popular beliefs, personal accounts through evocations of the subject. \\
\hline 37 th-40th & Facial expression & $\begin{array}{l}\text { Identification and categorization of facial expressions, context of facial expressions, creating a } \\
\text { context for the emotions, execution and guesswork of facial expressions. }\end{array}$ \\
\hline 4 Ist, 42nd & Emotional prosody & $\begin{array}{l}\text { Analysis of the voice on the emotions, relate them to situations and categorize them in } \\
\text { corresponding emotions, interpretation of dialogues with different intonations. }\end{array}$ \\
\hline 43rd & Linguistic prosody & Analysis of speech situations (statement, exclamation mark), interpretation and creation of dialogues. \\
\hline 44th, 45th & Narrative & Narration and creating stories. \\
\hline 46th, 47th & Retelling & $\begin{array}{l}\text { Retelling a story with as much detail as possible, intervening in memory and comprehension of texts } \\
\text { and stories. }\end{array}$ \\
\hline 48th & Narrative and retelling & Evocation of the intervention program highlights and closure. \\
\hline
\end{tabular}

Table S3 Mean scores and standard errors for language tests from institutionalized and noninstitutionalized groups with significant differences

\begin{tabular}{|c|c|c|c|c|c|c|}
\hline \multirow[t]{2}{*}{ Tests } & \multicolumn{3}{|c|}{ Institutionalized } & \multicolumn{3}{|c|}{ Noninstitutionalized } \\
\hline & $\begin{array}{l}\text { Before } \\
\text { stimulation }\end{array}$ & $\begin{array}{l}\text { After } \\
24 \text { sessions }\end{array}$ & $\begin{array}{l}\text { After } \\
48 \text { sessions }\end{array}$ & $\begin{array}{l}\text { Before } \\
\text { stimulation }\end{array}$ & $\begin{array}{l}\text { After } \\
24 \text { sessions }\end{array}$ & $\begin{array}{l}\text { After } \\
48 \text { sessions }\end{array}$ \\
\hline Boston Naming & $10.1 \pm 0.5829$ & $12.2 \pm 0.5935$ & $12.5 \pm 0.6979$ & $12.3 \pm 0.4 \mid 8$ & $13.2 \pm 0.407$ & $|3.3 \pm 0.409|$ \\
\hline SVF & $10.1 \pm 0.6372$ & $12.2 \pm 0.6589$ & $13.8 \pm 0.7869$ & $12.2 \pm 0.6819$ & $13.3 \pm 0.5753$ & $14.4 \pm 0.6818$ \\
\hline PVF & $4.92 \pm 0.7192$ & $6.94 \pm 0.7132$ & $7.86 \pm 0.8229$ & $6.97 \pm 0.846 \mid$ & $9.29 \pm 0.9404$ & $9.70 \pm 1.0788$ \\
\hline Key concepts (test of narrative) & $1.76 \pm 0.3478$ & $2.4 \pm 0.2828$ & $2.76 \pm 0.307$ & $3.24 \pm 0.2353$ & $3.29 \pm 0.3614$ & $3.53 \pm 0.3548$ \\
\hline Metaphors (explanation) & $17.4 \pm 1.6093$ & $22.68 \pm|.567|$ & $25.44 \pm 1.6218$ & $22.24 \pm 1.862$ & $26.12 \pm 1.8882$ & $28.18 \pm 2.0477$ \\
\hline DSA (explanation) & $8.72 \pm 0.694 I$ & $12.16 \pm 0.665$ & $14.08 \pm 0.6243$ & $10.82 \pm 0.6655$ & $|2.00 \pm 0.89| \mid$ & $13.59 \pm 0.9278$ \\
\hline DSA (alternatives) & $6.00 \pm 0.5831$ & $7.40 \pm 0.3873$ & $7.92 \pm 0.3693$ & $7.88 \pm 0.737 \mid$ & $7.82 \pm 0.6017$ & $7.59 \pm 0.6477$ \\
\hline ISA (explanation) & II. $.40 \pm 0.746 \mathrm{|}$ & $14.64 \pm 0.658$ & $16.84 \pm 0.4785$ & $|3.76 \pm 0.838|$ & $15.47 \pm 0.6593$ & $16.47 \pm 0.8407$ \\
\hline Emotional Prosody & $4.12 \pm 0.3282$ & $5.96 \pm 0.4564$ & $6.32 \pm 0.5407$ & $5.18 \pm 0.4308$ & $5.94 \pm 0.5249$ & $7.00 \pm 0.7276$ \\
\hline Partial retelling & $7.92 \pm 0.6555$ & $10.76 \pm 0.7556$ & I I. $68 \pm 0.7432$ & $9.94 \pm 1.0896$ & $10.65 \pm 1.3878$ & $11.59 \pm 1.4629$ \\
\hline Total retelling & $6.00 \pm 0.5$ & $7.20 \pm 0.5477$ & $8.68 \pm 0.5936$ & $7.06 \pm 0.6444$ & $8.53 \pm 0.7579$ & $9.29 \pm 0.7848$ \\
\hline Comprehension & $6.48 \pm 0.6883$ & $8.08 \pm 0.5713$ & $8.64 \pm 0.5594$ & $8.12 \pm 0.6907$ & $8.59 \pm 0.8047$ & $9.06 \pm 0.74$ \\
\hline
\end{tabular}

Abbreviations: MMSE, mini-mental state examination; SVF, semantic verbal fluency; PVF, phonological verbal fluency; Expl, explanation; DSA, direct speech acts; ISA, indirect speech acts. 
Clinical Interventions in Aging

\section{Publish your work in this journal}

Clinical Interventions in Aging is an international, peer-reviewed journal focusing on evidence-based reports on the value or lack thereof of treatments intended to prevent or delay the onset of maladaptive correlates of aging in human beings. This journal is indexed on PubMed Central, MedLine, the American Chemical Society's 'Chemical Abstracts

Service' (CAS), Scopus and the Elsevier Bibliographic databases. The manuscript management system is completely online and includes a very quick and fair peer-review system, which is all easy to use. Visit $\mathrm{http}: / /$ www.dovepress.com/testimonials.php to read real quotes from published authors.

Submit your manuscript here: http://www.dovepress.com/clinical-interventions-in-aging-journal 